\title{
Biologists urge US endowment for conservation
}

\section{One in five animal species may be extinct by the year 2000 , writes John Douglas}

AmID dire predictions about the future of tropical forests and endangered species, an international group of biologists has called on the United States government to establish a national endowment, similar to the national endowment for the arts, "to support original research, both theoretical and applied, in the area of conservation biology". The conference also called on governments and private groups of all developed nations to offer their support to establish and protect "some remnants of natural habitat in tropical countries". Both resolutions were adopted by acclamation at the end of a four-day conference on conservation biology at the University of California, San Diego, last week.

In recommending establishment of the new research endowment, the conference members cited the present lack of any appropriate US agency to fund and coordinate research in environmental management, wildlife biology and conservation. "In particular, we need an agency to fund research relevant to the stewardship of the Earth's remaining natural diversity". Specifically, the resolution calls for increased support for breeding programmes to help save endangered species, research on the ecology of endangered habitats, and an inter-disciplinary approach to the biology of conservation, environment, and animal populations.

To help preserve remaining tropical habitats, the conference again called on the US government to take the lead by launching a major programme "to and underdeveloped nations financially in establishing and protecting national parks and biological reserves". Otherwise, the resolution concluded, destruction of tropical forests may seriously affect climatic stability, soil erosion, water quality and economic development, "generally impoverishing human existence".

The plight of tropical forests was detailed in a paper by T. C. Whitmore of the University of Oxford. "The second half of the 20th century will stand in history as the brief period during which man reduced the area of the world's richest and most complex ecosystems to about one-third of their potential area", he said. "An onslaught has developed on tropical moist forests which is predicted to continue to accelerate to reduce them to scattered fragments by $2000 \mathrm{AD}$."

Between now and the turn of the century, the demand for tropical hardwood $\log$ production is expected to triple, said Dr Whitmore. That will require cutting 556 million hectares of forest, leaving only $30 \%$ (480 million hectares) of the total area under virgin conditions. Furthermore, the process of using bulldozers to retrieve the logs may compact as much as $70 \%$ of the soil in affected areas, hindering forest regeneration. "The prospect is frightening" he concluded.

Even if large national parks and game preserves are established, however, the loss of the great tropical forests will halt the further evolution of most tropical vertebrate species and drive many animals into extinction, according to papers delivered by Michael Soule and Bruce Wilcox of the University of California, San Diego. By using species data from island habitats the authors estimated the minimum area required for various animals to continue speciation. Even the largest of today's national parks are too small by an order of magnitude to foster continued evolution of large mammals, they conclude.

As a result of inbreeding and environmental accidents, Soule and Wilcox predict that the animals trapped in reserves too small for their continued evolution will begin to die out. Taking 19 East African national parks

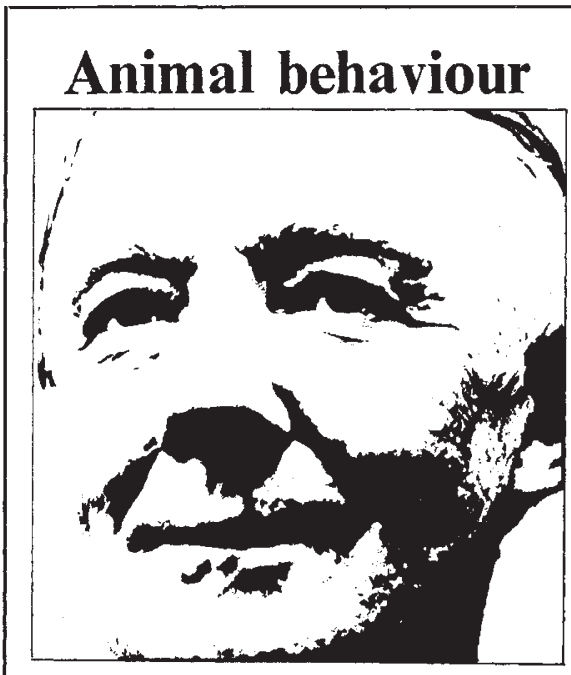

KENNETH MELLANBY

I WAS recently a member of a panel on a radio programme which discussed the topic "Do animals have rights?" The panel included representatives of animal protection societies and a scientist involved in research. The chairperson was a wellknown journalist and broadcaster. We had a live audience of about 200 and as an example, the researchers conclude that $11 \%$ of the large animal species will have become extinct in 50 years and $44 \%$ will be gone in 500 years, unless new management techniques are introduced. If present trends persist worldwide, only about $1 \%$ of the Earth's surface will remain in a preserved condition by the turn of the century, which would eventually lead to the extinction of perhaps 3.5 million of the known 5.0 million terrestrial animal species. One million may disappear just by the year 2000. "The ark is sinking" says Wilcox.

Several speakers addressed the question of how large a population of animals must be in order to avoid eventual extinction, and what breeding practices might be adopted to encourage the vitality of a species. Ian $R$. Franklin of the Genetics Research Laboratories (CSIRO), North Ryde, New South Wales, estimated that genetic considerations alone would require an "effective population" of at least 500 individuals. (Since not all members of a group of animals contribute equally to the gene pool of the next generation, the number of genetically "effective" individuals ranges between roughly half and threequarters of the total population.) Below the minimum population, Franklin says, the random loss of desirable traits,

the programme, with short breaks for advertisements, went on for an hour and a half.

The programme started with the chairperson asking the members of the panel to state, briefly, their views on animal's rights. All agreed that animals should not be made to suffer unnecessarily, but disagreed as to what suffering meant, and on obvious subjects like vivisection, hunting and factory farming. I thought that we should concentrate on man's responsibilities rather than on animal's rights. Domestic animals, cattle and sheep, and pets such as dogs and cats only exist because man breeds them, and controls the numbers which are born. Without man, most breeds would soon become extinct, though in some areas cats have escaped and become pests, endangering the native fauna. As man has created domestic animals, he has the responsibility for providing conditions where they do not suffereven conditions where we can reasonably imagine that they enjoy life. But if man disappeared from the world, so would most domestic animals.

The situation regarding wildlife is different. Wild animals, for the most 


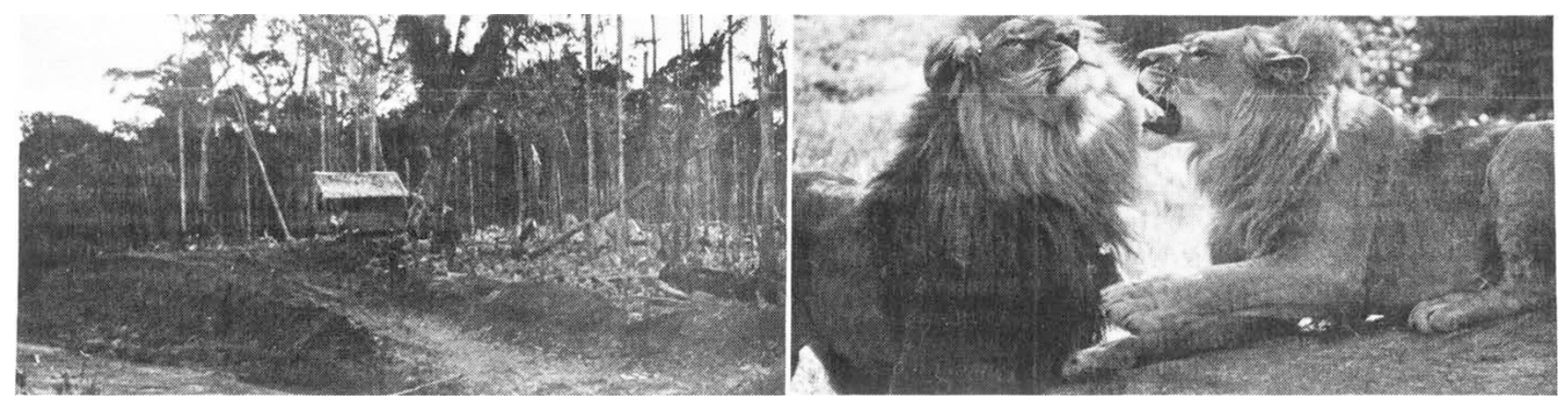

Left: trans-Amazonia highway and the jungle; right: maned lions each worth half-a-million dollars as Kenyan tourist attractions

called "genetic drift" will make a species unfit for survival.

Much of the problem of establishing and maintaining large reserves is economic: the need is greatest in areas encompassed by the world's poorest nations. William G. Conway of the New York Zoological Society concludes "The preservation of the majority of the animals that man finds attractive probably cannot be sustained on any provable economic basis". However, some nations, he says, have successfully used their preserves to bring in hard currency through tourism. In Kenya's Amboseli National Park, for example, a single maned lion is estimated to be worth $\$ 515,000$ as a tourist attraction, compared to only $\$ 1,150$ for commercial purposes as a skin.

For those animals that cannot be preserved in the wild, Conway suggests the limited use of zoos as "gene banks"

part, only continue to exist where man has left conditions-habitatssuitable for them. As a conservationist I think that we should do more to preserve and develop such habitats, even though this conflicts with the needs of agriculture to produce food for the growing human population.

Although the producer of this radio programme had tried to provide a balanced audience, and had invited farmers, those engaged in animal experiments, and sportsmen to participate, these groups were greatly outnumbered by those who considered themselves to be animal lovers. There were colourful and hirsute young men and drab girls wearing $\mathrm{T}$-shirts proclaiming them to be hunt saboteurs. We had anti-vivisectionists of all persuasions, vegetarians, some milk drinkers, some vegans, and some who seemed mainly to wish to oppose the politics of the establishment. Although there were good questions and sensible comments from the floor, the majority of the audience had not come to listen or to discuss. Their purpose was to stop those with whom they disagreed from speaking.

Thus when one panel member tried until future generations can be reintroduced into the wild. With careful mating, the number of individuals needed might be as small as 50 to 100 animals, he says, but even then half their genetic diversity would be lost and only 100 species could thus be maintained if half of all the zoo capacity in the United States were marshalled to the task.

Another way to preserve species by making some of them more profitable to indigenous people was discussed by Malcolm Coe of Oxford. The oryx, for example, is better adapted to life in Africa than cattle, he said, and some domesticated herds of eland, springbock and greater Kudu have been established. Another advantage of using such wild ungulates for food comes from their high proportion of lean meat $-43 \%$ compared to $23 \%$ of the carcass of cattle raised under the same

to give the correct breakdown of the number of animal experiments in Britain, showing that these were mostly for genuine medical tests and not just to swell the profits of cosmetic manufacturers, a section of the audience, largely consisting of remarkably unattractive women resembling those who knitted when the guillotine functioned in revolutionary France, bayed "Lies, lies, lies, sit down, we won't listen to your lies". When I was asked about the policy of culling red deer in the Scottish Highlands, and said this was necessary to keep the population healthy, as otherwise, as wolves and other predators which controlled numbers were no longer present, the deer would increase until many died from starvation and disease, someone shouted: "Why not cull human beings?" The noise made by the audience was quite alarming, and made the interruptions heard at question time in the British parliament sound almost human.

I am afraid that my main reaction to the evening's entertainment was to wonder why those who profess to love animals hate their own species so much! conditions. Even crocodiles might be raised as a valuable cash crop, since their hides bring a high price and they grow much faster in captivity.

The generally sombre message of the conference was phrased in particularly vivid terms by Thomas E. Lovejoy of the World Wildlife Fund. Between $50 \%$ and $85 \%$ of all species on Farth have yet to be named, he said, and a major fraction of these may pass entirely out of existence still unrecognised. They will be replaced by the quickly evolving, highly productive species that can coexist with man, often as pests. "Cockroaches and Norway rats will loom larger in 21 st century bestiaries," says Lovejoy, "as will crabgrass and dandelions in the floras".

\section{Bison trouble}

Byelorussia has been facing a somewhat unusual hazard of conservation at the-literally-grass-roots level. The primaeval Bielaviezkaja forest is a reserve for, among other species, Europe's last remaining bison. Virtually exterminated during the war, the bison herd is now multiplying in a most satisfactory manner, and it is hoped shortly to remove the bison from the Red Book of endangered species.

In the meantime, however, bison can occasionally cause problems - as certain collective-farmers found this summer. On the "Komintern" collective farm near Barysau, one particular bison claimed as its range a large hayfield, chasing the only farmer who dared approach it up a tall tree.

Denied more "radical means" of cvicting it, the Farm Management Board decided to leave the field to the bison - whereupon several other bison moved in. To date no information is forthcoming as to whether the bison have been dislodged.

This is not the first time that forest bison have caused disruption of local life; a few years ago, at Hajdowka on the Polish side of the forest, one of the local bison went to sleep on the railway lines, following this exploit by a visit to the local school. 